Apart from the research work connected with the college, we gather that an increasing use is made of this institute " as an advisory centre on matters relating to agriculture and horticulture, so much so that in future years each department of the work of the college will have its special journal." In the section devoted to the report of the economic zoologist, Mr. F. V. Theobald, no less than 119 pests are dealt with, chiefly under the following heads:- those injurious to man's domestic animals, to fruit trees, to pulse, hops, and vegetables, flowers, forest trees, food-stuffs, and those causing annoyance to snan; and beside these are some replies to Extra-British inquiries. One of the more interesting portions, issued from this department, is that dealing with the habits of the woolly aphis (Schizoneura lanigera). The author has conclusively proved that the damage done by the root form of this pest is much more severe in this country than has been generally supposed. In view of this, Mr. Theobald attributes the failures in treatment because we have hitherto ignored the presence of the migrating ground form. An in-

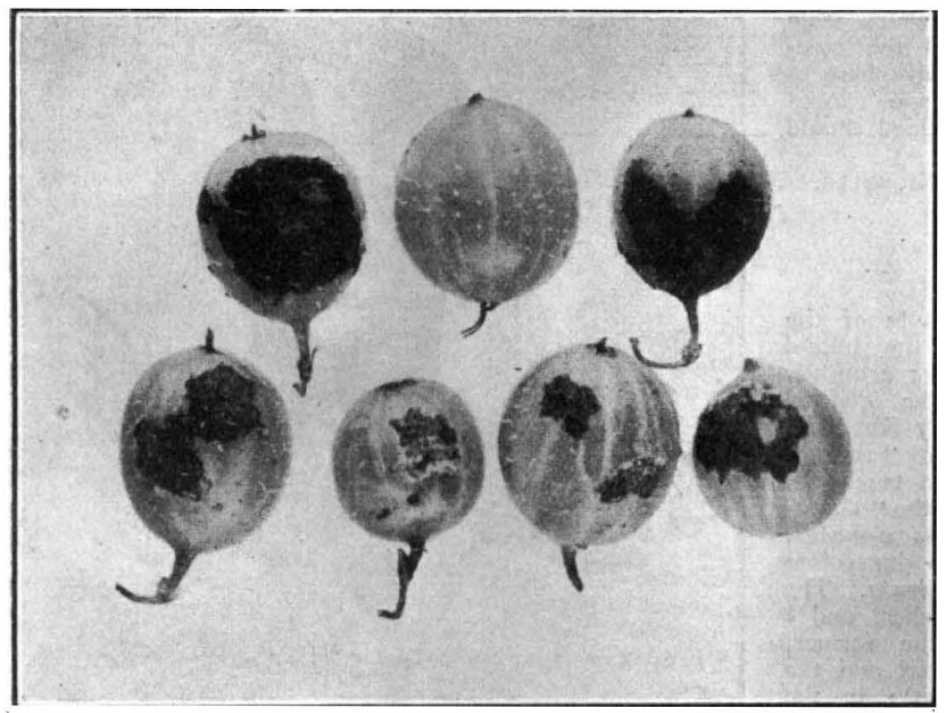

FIG. 2. - Six nearly ripe gooseberries which have been attacked by the American Gooseberrymildew; one healthy berry is shown. (From Ireland.)

jection of carbon bisulphide is recommended for the terrestrial, and a caustic alkali wash for the arboreal form. In a short note on the habits of the house fly (Musca domestica), this insect is said to "have bred largely in rotting cow-dung mixed with vegetable matter." We may add, however, that in one of our largest cities, stable middens and ash-pits form the chief breeding places for this fly; anything in the form of decayed vegetable matter, such as the dung of pet animals, vegetables, or even paper, provides food for the larvæ, and more especially so where heat is engendered.

Messrs. H. F. Annett, F. V. Darbishire, and E. Russell furnish the report from the analytical laboratory, in which it is stated that $25^{\circ}$ samples of various substances were sent in for analysis during the past year. A detailed account is given of some of these; others are dealt with briefly. They are treated under the following heads:-Manures, feeding-stuffs, poisons, milks, waters and soils.

The reports from the botanical department are contributed by the four members of the staff. Mr. E. S. Salmon, the mycologist, has given evidence of his

Nก. I 998, voL. 777 energy in turning his extensive knowledge of fungi to practical account for the benefit of fruit growers in this country. The detection of the outbreaks of American gooseberry mildew (Sphaerotheca morsuvae) (Figs. I and 2) by him was followed by an energetic and tactful campaign to bring about the stamping out of the disease, and his efforts have been rewarded by the introduction of the Bill dealing with fungus attacks into the House of Lords. The Board of Agriculture and Fisheries has now made an order which may be cited as the Gloucestershire and Worcestershire (Gooseberry Mildew) Order of 1907. It came into operation on July 22. This constitutes the first legislative measure against fungus diseases put into force in this country. The fungoid disease of the gooseberry was discovered in the winter of I9o6 in some commercial plantations in Worcestershire and Gloucestershire, but it had previously been introduced into Ireland on diseased stock imported from America. It is during the so-called " summer stage" that this mildew spreads most rapidly, as at this period the chains of Conidia are produced in continuous succession day and night. We gather that the cherry orchards in certain portions of Kent are still seriously affected by the fungus Gnomonia erythrostoma, which depends " absolutely for the continuance of its existence on fresh infection taking place in spring by means of the spores scattered from the fruit-conceptacles of the fungus on the dead leaves hanging on the tree." R. N.

\section{THE GEOLOGY OF THE} TRANSVAAL.

THE most interesting features of the report of the Transvaal Geological Survey for the year 1906 are the excellent pieces of detailed mapping of the rocks of the Transvaal System, in the Lydenburg district, between Lydenburg and Belvedere, by Mr. A. L. Hall, and in the area immediately east of the Crocodile River and south of the Rooiberg by Mr. W. A. Humphrey. These two districts form parts of the same great synclinal trough; but while the I,ydenburg district is at the eastern end of the trough, and is as remarkable for the simplicity of its geological structure as it is famous for the grandeur of its scenery, the area mapped by Mr. Humphrey lies 200 miles to the west and nearer the centre of the trough, and is characterised by an exceptionally complicated structure. Surrounded by the much later Red Granite formation, the isolated inliers of the Transvaal System in the latter area owe their position to faulting and folding on a large scale, an adequate explanation of which can only be forthcoming when the area to the west is mapped in detail.

In both districts the three members of the Transvaal System are developed-namely, the Pretoria Series, the Dolomite, and the Black Reef Series. The quartzites of the Black Reef Series, which form the lowest division, attain to an unusual development in the northern part of the L.ydenburg district, where they form the main portion of the great escarpment of the Drackensberg, and play a considerable rôle in determining the wild character of the scenery.

1 Transvaal Mines Department. Report of the Geological Survey for the Year 1906. (Pretoria, 1907.) Price 7s. 6d. 
"No mere description," says the author, "can convey an adequate idea of the grandeur of the country between Belvedere and Blyde River Poort, where this stream enters the granitic Low Veld area." The escarpment of the Drackensberg " here forms a fine semi-circular curve, cut into by a number of spruits which give rise to precipitous and densely wooded kloofs. Immediately below the edge of this escarpment runs a massive kranz of quartzite nearly 5oo feet in thickness." About a thousand feet below lies the great plain of the Low Country, beyond which, on a clear day, the distant chain of the Lebombo Hills can be discerned. The dip of the Black Reef Series being to the west, the escarpment rises eastward until it culminates in two magnificent bluffs, 3500 feet higher than the Belvedere (see Fig.). North of Belvedere the greater thickness of the quartzites produces, under the profound erosive action of the

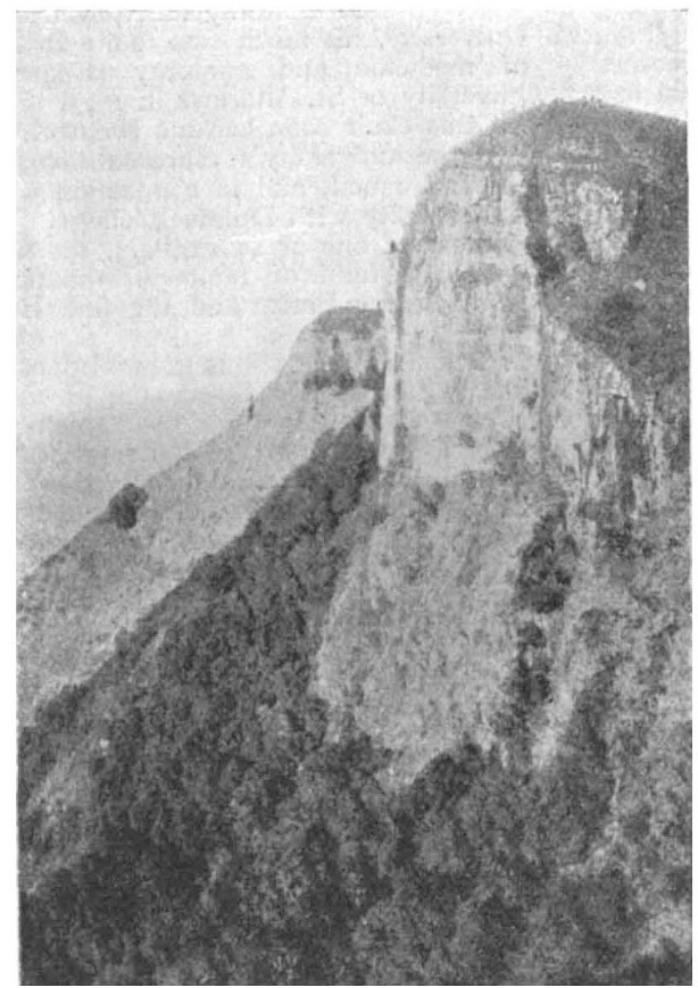

Pcrtion of the Great Fastern Escarpment of the Drakensberg, S. of Belvedere, formed by the Black Reef Series.

larger rivers, even more striking scenic effects. Thus the Blyde River is mentioned as having carved out a cañon in the quartzites to a depth of more than 2000 feet.

The Dolomite, owing to its more homogeneous composition and consequent absence of marked horizontal features, is characterised by a different type of scenery. Its vertical jointing, however, gives rise to peculiarly pointed kopjes, recalling portions of the dolomite area in the Tyrol. Northward, from Pilgrim's Rest to Hermansburg, the Blyde River flows in a gorge formed by precipitous walls of dolomite. It then travels in a more open valley; but on leaving the Dolomite it cuts its bed down into the Black Reef quartzites by a succession of cataracts and waterfalls until, joining forces with the Treuer River and the Belvedere Creek, it forms the deep cañon mentioned above.

NO. [998, VOL. 77]
The Pretoria Series presents in the Lydenburg district no feature, either topographical or geological, of especial interest; the same succession of shales, quartzites, and intrusive sheets is met with as in the country further south. The only noteworthy point is the marked thinning out of the series which is observable to the north of Lydenburg. The middle member of the system-..the Dolomite-undergoes no great change in thickness, although a thick bed of quartzite (the " Blyde Quartzites ") makes its appearance for the first time in the middle of the series; but while the upper member-the Pretoria Series-becomes much attenuated, the lower member - the Black Reef Series-rapidly assumes greater and greater proportions as it is traced northwards. In the extreme eastern portions of the Rand basin, near Springs, the boreholes put down through the Karroo Coal-measures and the Dolomite, to cut the underlying Witwatersrand Beds, showed that the Black Reef Series was represented at the base of the Dolomite by a bed of hard quartzite only 20 feet in thickness (see Hatcn, Trans. of the Geol. Soc. of S. Africa, voi. vii., rgo4, p. 63). At the Devil's Kantoor, in the Barberton district, it is I ro feet thick; at Mac-Mac, zoo feet; at Belvedere, I260 feet; while near the northern termination of the Drackensberg, at Marieps Kop, the series reaches $255^{\circ}$ feet. The horizontal distance across the syncline formed by the beds of the Transvaal Svstem, under the Waterberg and Red Granite formations, from Springs to the Drackensberg escarpment, is only about i6o miles, so that the conditions of sedimentation must have changed rather rapidly, the cause of which is not explained.

It will be seen by the free use made of Boer topographical words in the sentence quoted above that the committee appointed by the British Association at its last meeting "to determine the precise significance of topographical and geological terms used locally in South Africa "' should serve a useful purpose. The precise meaning of such words as kranz, bult, vlei, and kloof will not be known to the generality of English readers, although kopje, veld. and spruit may have been made familiar by the late war. The report is accompanied by excellent colourprinted maps, and illustrated by beautiful photographic reproductions; but, unfortunately, it lacks an index, and has not even a paged table of contents.

F. H. Hatch.

\section{THE HISTORY OF ARITHMETICAL \\ NOTATION.}

THE invention of the decimal notation, which involves the use of zero and the assignment of local value to digits, made such an immense alteration in the character of arithmetical calculations that it would be extremely interesting to know its origin. It became familiar in Europe mainly through Mohammedan sources; hence the term Arabic, as opposed to Roman notation. But the discovery of Sanskrit literature and of Indian works on mathematics led to the theory that the real inventors of the system were the Hindus. The object of Mr. Kaye, in the paper referred to below, ${ }^{1}$ is to show that this conclusion has been based on insufficient evidence, and that the whole question requires further and more careful consideration, including a critical study of Indian texts, to avoid being misled by spurious documents. Mr. Kaye gives in the first place a series of arguments which go far to prove that there is no trustworthy evidence for the use of the new notation in India

1 "Notes on Indian Mathematics.-Arithmetical Notation." By R. Kaye. (Journ. and Proc. As. Soc. of Bengal, new series, vol. iii., No. 7, 